\title{
New Value-Behavioral Structures and Hierarchies in the Technical Academic Education in the Context of Romania Integration in the European Union
}

\author{
Tiron Elena \\ Department of Teacher Training, Gheorghe Asachi Technical University of Iasi, Iasi, Romania. \\ Email: elnorit@yahoo.com \\ Received February $10^{\text {th }}, 2011$; revised March $1^{\text {st }}, 2011$; accepted March $15^{\text {th }}, 2011$.
}

\begin{abstract}
The work is structured in 4 parts: I. Conceptual differentiations: value, belief, norm, mentality, attitude, interest, opinion, need, behavior; II. Restructuring scheme of the personality axiological components in a determined context; III. Professional values in the technical academic education: identification and hierarchy; IV. Conclusions. In the first part, there are made conceptual differentiations between the notions of belief, norm, mentality, attitude, interest, opinion, need, behavior, emphasizing thus on mutual aspects. In the second part of the paper, there is presented the global structuring of the axiological universe, the determinant factors of the value hierarchy change in a given social-economic context, there is elaborated a new re-structuring scheme of the value components, there are identified specific mechanisms to the present Romanian society resistant to the value authentic change. In the third part, there is described D. E. Super's theory that stands at the basis of the elaboration of the Professional Value Inventory. This was applied in our research on a sample of 120 students from the two technical faculties, getting thus a certain professional values hierarchy. The conclusions emphasize the confirmation of the two hypothesis, the extrinsic motivating factors of the professional choice, behaviors and attitudes definition, values through immediate, material profit, of the individual welfare.
\end{abstract}

Keywords: Value Hierarchy Change, Professional Values, D. E. Super's Theory, Technical Academic Education

\section{Conceptual Differentiations: Value, Belief, Norm, Mentality, Attitude, Interest, Opinion, Need, Behavior}

The term value is specific to philosophy, being the core of one of its sub-branches: axiology that studies genesis, structure, interaction, knowledge, accomplishment, hierarchy and functions of the values in social life, the correlation among them, and the dynamic of the value systems.

In explaining the meanings we give to the term value, an essential role belongs to: - the people's purposes, projects, wishes, intentions - the creative activity from every field - the social relationship by which there is filtered the importance of the created products for that society. The valorization act is constituted at the level of social awareness, having priority compared to the preference acts that take place at the level of individual awareness, although it is realized only by this.

Each epoch, each social organization, each social class, each social community admits a certain value system. The historical and social changes amend both the valorization criteria and the ones of the value hierarchy. The axiological criteria are $d y$ namic, they change according to a dialectic that is determined by the evolution of the social-global system. The value presents poly (good-evil, beautiful-ugly, right-wrong) and degrees which lead to a disjunction between the positive and negative values and the set-up of a value hierarchic order variable for each social group or class.

At the same time, there are general-human values without which the human life together isn't possible. Value creation always involves going beyond the present, inferring the devel- opment sense of other fields of the social life.

From the psychological point of view, the problematic of value and valorization is extremely complex. That is why we consider necessary to analyze comparatively the meanings of the term value, making the necessary references to the concepttions with deeper psychological load both from a social point of view and of the individual: belief, norm, mentality, attitude, interest, opinion, need, behavior. The first terms of belief, norm, mentality have a psycho-sociologic shade more intense, and the others are more shaped from a psychological point of view.

The term belief means determined opinion, strong conviction, subjective certainty on a fact or relationship that is obvious, and sometimes can not even be proved. The social norm is considered a rule that prescribes accepted behavior by a collectivity or by an institution. Mentality is defined as an organizing manner of the intellectual activity, considered from the point of view of the logical structures, and of the affective directing values, as the convictions and beliefs are. Attitude represents the relatively constant activity to relate the individual or the group to certain aspects of the social life and to his person, orienting-regulatory structure belonging to the person's system or to the sintality. Interest is defined as a correspondence report between the internal demands subject's tendencies and a series of objects and actions, so that the subject orients himself actively and of his own initiative towards those objects and actions, and these present a major importance for the subject, attract him and give him satisfaction. Public opinion is psycho-social phenomenon which content is given by the generalized appreciation of a collectivity. Need had to be understood as the personality energetic-pulsatory dimension, subjective 
that is at the bases of this dynamics.

Behavior is the complex of the adaptable reactions, objecttively-observable, that an organism having nervous system executes as a response to the environment stimuli that are also objectively-observable.( According to the Psychology Dictionary, Albatros Publishing House, 1978).

From the comparative analysis of these terms we notice that:

- they all refer to a relationship, to a report between objective and subjective, between individual, person with his demands and subjectivity and environment, psycho-social context;

- the analyzed terms express the degree of correspondence, appreciations, valence of the subjective aspects in relationship with the objective ones;

- the meanings of these terms are cognitive, affective, volition-behavioral.

Belief has a strong affective-volitional characteristic, norm is mainly volitional, mentality is cognitive-affective, attitude is orienting-regulatory, behavior is volitional-active.

From this results the importance of the psycho-social context, of the social-historical period when we analyze these concepts.

The relationship among these concepts is emphasized by several authors. Allport defined attitude as a neural and mental status, organized through experience that exercises a dynamics on the individual's response to all the objects and situations he is related with.

Considering that attitude is an indispensable concept both in social psychology and of the personality, M. Rocheach understands attitude as a durable organization of the convictions about an object or about a situation predisposing the person to respond in a preferential manner. R. Linton refers to the attitudes-value system. Once set in the individual, attitudinal-value systems act automatically and mostly subconsciously. Emphasizing the value content and the evaluative function of the attitude, Kretch (1962) defined the emotional feelings as a system of positive or negative values, with tendentious actions, pro or against that regard the social object. The ethnologists prove convincingly that the attitudes are acquired, learned, and although their stability they are susceptible to modifications under the influence of circumstances and by recurrent effects of exercising them. G. H. Mead, A. Kardiner, R. Linton proved attitude formation by acquiring cultural models. V. A. Measiscev insists on the fact that attitude disposes of an inciting-orienting component, of a selective-evaluative one and of an effectory component, strongly operative. Kretch - distinguishes attitudes: simple, uni-dimensional and multi-dimensional, those are to be found at a heterogeneous group of objects. Taking into consideration the correlation between attitudes, their organization in hierarchic systems, they can be: central and periphery, dominant and subordinate.

Depending on their stability and strength degrees, the attitudes enter in the character system as its components.

The attitude changes are appreciated according to the parameters of: complexity, constancy, inter-relationship, consonance, value position, motivational intensity.

\section{Restructuring Scheme of the Axiological Components of the Personality in a Determined Context}

Value, attitude and interest problematic reflected in the in- ternational psycho-sociological research from the past 5 years emphasizes certain trends: inter-changeability of these concepts, but also their differentiation in structural constellations, mainly socio-cultural genesis of the phenomena reflected by these concepts, mechanisms of value-attitudinal structures introversion, central-integrative functions, but also evaluative of the values in the personality configuration, factors of attitudinal change. P. Ilut (2004) realizes an analogy between the factorial hierarchic personality structure and the person's axiological profile, setting the values as general principles about desideratum, in the center and above, these being transcribed in norms and attitudes, and the attitudes being specified and expressed in opinions. The central role of the values in the personality axiological structure is divided both in older studies as well as in modern actual researches.

Thus for this second instance, P. Smith and S. Schwartz (1997) identify five more important aspects of the values:

1) Values are ideas, but not cold ones, but infused with sensitivity;

2) They refer to desideratum purposes and to behavior ways by which those purposes are promoted;

3) Values transcend specific actions and situations;

4) They are ordered both at society level as well as at the individual level, forming value systems;

In the issue of the value genesis and nature, it is reiterated the report universalism-contextualism described in philosophy, anthropology, social psychology in previous studies and researches. R. Boudon (1994) considers that the cognitive approach, of neo-Weber nature can solve the epistemic tension between universal and contextual in the axiological problematic. The cognitive solution proposed by Boudon refers to the correlation between a certain axiological rationality and the valuemoral options of the social actors according to the types of situations. The researcher's task is to re-construct the people's value judgments, in the actual living of their lives. Continuing this idea, Tirhas (2003) introduces the concept of multimodal personality in opposition with the older notion of modal personality. In the context of a certain society, the modal personality that would represent the most frequent personality type is difficult to confirm from the experimental point of view (A. Wallace, 1952). Tirhas shows that post-modern societies are built for the same socio-cultural space in several personality types, the society having a multimodal personality. But this doesn't induce chaos and essential contradictions in the context of the axiological social and individual context. P. Ilut sustains the global structuring of the axiological universe in the following levels:

1) general-human values,

2) values of a socio-political system,

3) values belonging to a certain culture and ethnicity,

4) values of the big and middle-sized social groups (social classes, professions),

5) values of micro-groups,

6) individual values.

The phenomenological problem, but also of research consists in the homogeneity/heterogeneity of the personality axiologycal structure, in the relationships and hierarchies that are established between these types of values according to different criteria at the society and individual.

The attitudes and interests are at a subordinate level to values and norms, having a pre-dispositional constant, evaluative and 
pragmatic character. R. Baron and D. Byrne (2000) use in their social psychological text book for the concept of social cognition the verb to think about the social world, and for attitudes the verb to evaluate the social world. Chelcea (1994) sustains that attitudes represent a person's or a group's positions to accept or reject, with a higher or lower intensity, objects, phenomena or persons, groups, institutions, etc. Attitudes are formed by social and observational learning (Bandura), by social comparison (Festinger), by reflexivity and analysis.

Thus when the issue of changing value structures and hierarchies is formulated, in certain periods of passage from one social-political system to another, the change starts with pragmatic components, interests, attitudes, in order to stabilize at the superior axiological value level. Petty and Wegennen (1998) realize in this respect the scheme of the general structure of the interaction between the attitudinal change factors. They identify the mutual interaction relationship among the change source, the transmitted message, the target receptor and the context as well as the determination of the affective, cognitive and behavioral processes from this interaction. But the attitudinal change faces many obstacles as for example: selective exposure, source credibility depreciation, message distortion, replacement, attitudinal reactive polarization, etc. Attitudinal change is opposed the resistance to change, that is also localized at the level of the source, of the message, of the receptor, of the change context. I. Caccioppo (1996) shows that the change efficiency depends on the degree in which the subjects elaborate cognitive responses to the message. He considers that there are two elaboration itineraries to these responses: - central itinerary that it is characterized by the fact that the receptors analyze and interpret the arguments strength, - periphery itinerary, when the receptors relate themselves to external aspects, of attractiveness, at the form of the message, at the circumstances in which they receive the message.

In socio-historical periods of radical transformations, in social, economic, cultural, scanty situations, there appear attitudinal confusions, there develop impression motivations (Chaiken, 1996), divergences among values, attitudes, interests and behavior. In this respect, Sears and colleagues (1991) elaborate a model of the thought action referring to the more flexible relationship attitude behavior and that prepares the value change. The behavioral change is understood as a deliberate change that depends on one's own attitudes, but also on the introverted social norms, and at the end on the evaluation of the behavioral consequences by the subject, on the probability of these consequences, on the behavior approval by important persons to the subject.

Relating ourselves to the definition and structuring of the value-attitudinal components in the specialized literature ( $\mathrm{S}$. Schwartz, P. Smith, 1997, P. Ilut, 2004), we propose the following re-structuring scheme of the axiological components in Figure 1.

As far as the cognitive approach that R. Boudon (1994) proposes to solve the universalism-contextualism dilemma in the field of axiological phenomena, we consider that all axiological systems have a hard, trans-societal core of general-human values and specific value-attitudinal components, that are built by introversion mechanisms of the society demands, at the level of social groups, institutions and persons.

At the present transition level of the Romanian society, we consider that there can be efficiently applied Kohlberg's Model, with the three development levels of morality: preconventional,

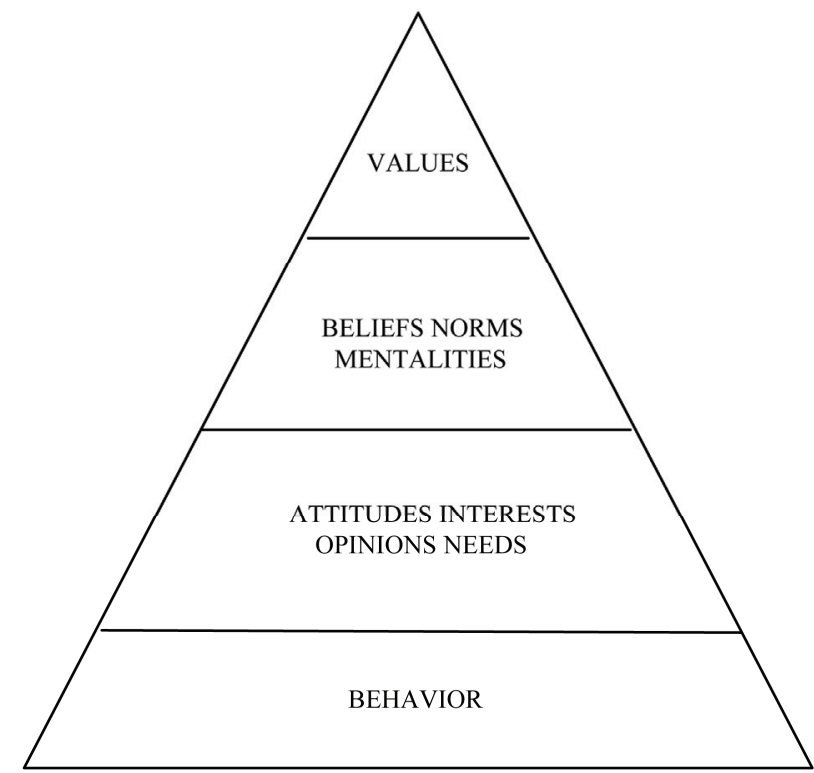

Figure 1.

The scheme of the axiological components.

conventional and post-conventional. The Romanian transition society is at the pre-conventional level, when the morality is under the sign of personal gratification. Personal interests, no matter if they are convergent or divergent with the group ones, are during this period a priority to the collective interests. Personal gratification and obtaining some rewards are considered by us to be the psycho-social mechanisms that justify the pre-conventional level where the morality of the Romanian society is.

During the re-evaluation and re-constructing process of the value-attitudinal structures, specific to the democratic societies is the value pluralism. But due to its specific context, Romanian society is at the level of the value relativism, of the value crisis, of the value confusion. The value instrumental functions, the ones utilitarian-narrow are predominant in the Romanian society as well as in the Western society of the 60s (D. Katz).

Social learning faces great non-functionalities because of the scanty models, unknown to the Romanian cultural-religious spirit, but also because of the Romanian axiological space deformed by Communism. The specific mechanisms to the Romanian society resistant to change are: foreign models inoculation, non-critical assimilation, extreme attitudinal polarization that lead to value confusion, decrease of the exactingness of the educational factors, reactivity that is concretized in negative attitudes towards change.

During this axiological confusion period, the pupils and the students of the technical education - we can say that - use according to I. Caccioppo' conception (2000) more the periphery itinerary than the central one, elaborating cognitive responses based on appearances, form and circumstances.

But many social psychology researches show that stress moves from the instrumental needs and values to the expressive ones, from the institutional self to the intimate one (Mynatt and Doherty, 2002), when the biological and social certainty needs (A. Maslow) are satisfied, and the institutions work normally. 
We consider that these are the solutions also for the Romanian society. The value-attitudinal change is possible, but on long term, as a consequence of the economic, socio-political and educational factors convergence.

\section{Professional Values in the Technical Academic Education: Identification and Hierarchy}

At the basis of the value identification and hierarchy, generally and of the professional values especially, there stand several researches that lead to the elaboration of some different theories and concepts: - theories about the personality characteristics and factors, Parsons (1909), Kitson (1925), Hull (1928), - psych-analytical theories about career, Hendrik (1943), R. Foser (1953) Malning (1967), Neff (1968), — theories about psychological needs and of the personality values Murray (1938), Maslow (1954), Darley and Hogenah (1955), Wolf (1970), —-theories about social systems, C. Miller, W. H. Form (1951), T. Caplow (1954), M. Harmany (1964), W. H. Sewell and R. M. Hauser (1975), - theories about the development of the self concept, C. Buchler (1933), E. Gingsberg and his collaborators (1951), J. Samler (1953), R. Happock (1957), C. H. Miller (1974), that include G. W. Allport, D. E. Super, E. H. Erikson and P. Lazarsfeld's ideas, - theories about career planning (management of the professional career) (Ion Murgescu, 2006).

E. D. Super is the one who proposed the theory of the development of self concept, applied to the behaviors specific to the professional choice. The individual's options are influenced by self image and information about the jobs world. The option for a certain profession is not just a decision moment, but also a process and a succession of intermediary choices made in different life moments and related to various levels of growth and development and ability, aptitude and skill exercising, in various lifestyle situations. The professional orientation is for Super the process by which a person is supported to develop and accept a complete and adequate image about the self and about the his/her role in the labor world and is helped to test this role in front of the reality, in order to obtain the self satisfaction also in the best interest of the society.

From the theory analysis those results that the counseling and orientation services need to have a continuous character during the individual's evolution especially in the steps before the great decisions: the choice of the school, of the profession, of the work place, in the moment of re-qualification and retirement.

This theory is built around 14 statements:

Statement 1: People are different by their capacities and personality, by their needs, interests, characteristics and conceptions about self.

The conception about the self is defining for all the life roles, being part of this also the professional role in a certain career.

Statement 2: People are qualified in the virtue of these characteristics for several professions.

Statement 3: Each statement needs a certain specific model of personal qualities and features, with a quite big tolerance in order to afford a certain variety of individuals for each professsion.

These two statements are optimist as far as the people varied possibilities to have several professions, occupational multi- determination starting from the same quality complex, but also from different quality systems for the same profession.

Statement 4: Professional preferences and competences, the situations in which people live and work and as a consequence their conception about the self, are modified in time and with experience, although self conceptions as a product of social experience are more and stable starting with the end of adolescence and to the late maturity, providing a certain continuity in options and adaptations.

Statement 5: This change process can be added to s series of life stages (a maxi-cycle) characterized a sequence-growth-exploration-stabilization-maintenance-disengagement and these stages can be sub-divided at their turn into periods characterized by certain supposed development tasks. A small cycle (mini-cycle) there appears in the career transition period from one stage to another when a individual's career is destabilized because of a disease or an accident, of staff reduction, social changes, in the needs of human resources or other socio-economic or personal events. Such an unstable career implies a re-cycling, a new growth, re-exploration and re-stabilization period.

Statements 4 and 5 explain the preferences and professional competences dynamics as a consequence of the life experience and thus as a consequence also the career change possibility from one stage to another of even of the profession.

Statement 6: Career model nature, that is the occupational reached level and the succession, frequency and trials of the jobs is determined by the socio-economic level of that person's parents, by the mental capacity, education, personal qualities and characteristics (needs, values, interests, self conception) and career maturity, as well as the opportunities to which the person is exposed.

Socio-economic life environment, cultural and education context, person's features, values and self conception have an essential role in the career choice, keeping and change.

Statement 7: The success before the environment and organisms demands depends in all the career stages on the individual's availability to comply with these demands (in the maturity period of his career).

The career success cannot be obtained without the person's availability to make efforts to comply with the high demands of his career.

Statement 8: Career maturity is a psychosocial concept that designates an individual's development degree during the continuous evolution represented by the life levels and sub-levels from growth to disengagement. From the social or society perspective, career maturity can be defined operationally by comparing the development tasks with which the individual confronts to the ones the people around him expect to be fulfilled by him in certain stages of chronologic age. From the psychological perspective, career maturity is operationally defined by comparing the resources of which the individual disposes both from the cognitive and affective point of view in order to comply with a current task, with the necessary resources in order to solve that task.

Career maturity is seen both from the social point of view as a report between the person's possibilities and the expectations of the persons around him to solve the tasks, as well as from the psychological point of view as a report between the person's resources and the resources necessary to solve that task. 
Statement 9: Development in various lifetime stages can be directed partly by facilitating qualities and interests maturation and partly by the help given in testing reality and self concepttion evolution.

Self conception evolution is considered the lever of the person's development and of his career.

Statement 10: Career development process is essentially the evolution and implementation of the occupational concepts about the self. This represents a synthesizing and compromise process where the self conception is a product of the interaction between inherited aptitudes, physical building, opportunity to notice and play different roles, and evaluation of the extent in which the play role results receive the approval of the superiors and generation colleagues.

Flexible interaction between the person's aptitudes, her qualities and the availability to play different play roles lead to career development.

Statement 11: The synthesizing process or the compromise between the individual and social factor, between the own concepts and the reality is a role play and of learning by feed-back, no matter is the role is played in fantasy, in a counseling interview or in real life activities as classes, part-time, volunteer work, etc.

Social learning, in school, in a counseling process or in real life realizes the compromise between the social and individual factor.

Statement 12: Satisfaction offered by work and satisfaction in life depend on the extent in which the individual finds the adequate modalities to express the qualities, needs, values, interests and features of his personality and of the self concepttion. Satisfaction depends also on the stabilization of a certain work type and lifestyle in which he can play the role the individual considers fit and adequate to his personality.

If by his profession the individual manages to implement the self conception, this offers him satisfaction.

Statement 13: The satisfaction degree that the people get from the work made is proportional to the extent in which they are able to implement their self conceptions.

This statement reinforces the role of the self conception in obtaining a higher degree of work satisfaction.

Statement 14: Work and profession involve an attention given to personality organization for most men and women, although in the case of certain individuals this attention is peripherical, incidental or even inexistent. Other elements can be essential in these cases, for example spare time activities or those related to the housekeeping. Social traditions as for example modeling the stereotypes based on sex, ethnical and racial differences and opportunity structure as well as individual differences represent important determinants of the preferences for the role of student, worker, holiday maker, family member and citizen.

Super shows that the role of work is absolutely fundamental in the case of most of the persons.

Professional values constitute a sub-system in the personality axiological system: they refer to the particular aspects of the professional activity that are more or less desired (Super, 1970).

According to some thorough psycho-sociological researches for two decades, D. E. Super identifies 15 professional values. Here is the way they are presented in the work "Etude de l'inventaire des valeurs professionelles" ("Study of the Profes- sional Values Inventory") by M. Huteau and D. Pouzols (1974):

1) Altruism: "the possibility to contribute at others' welfare". Altruism allows the oriented evaluation towards social services. The obtained score is, most probably, influenced by social desirability.

2) Aesthetic values: values that manifest themselves in the activities that "allow making some aesthetic objects and contributing to embellish the world" we live in. Aesthetic values are associated to artistic and handcrafting interests.

3) Intellectual stimulation: associated value to "a profession that offers the opportunity of an autonomous reflection and gives the possibility of continuous learning". The persons who have interest for scientific activities of abstract type obtain high scores at this professional dimension.

4) Professional success: value that reflects a profession appreciation that gives the individuals the feeling of satisfaction for the thing well done. This dimension expresses the orientation to the activities with tangible, visible results.

5) Independence: value associated to professions that allow to work according to one's own planning, in the rhythm set by the individual. Social desirability tends to reduce the score at this dimension.

6) Prestige: value attached to "professions that confer importance to those who exercise them and impose respect". This dimension reflects the interest for professions that involve business relationships.

7) Leadership: value that manifests in the "professions that give the possibility to plan and organize others' work".

8) Economic advantages: value that reflects the orientation towards better paid professions. It is possible that in the present transition situation to the market economy, the score at this direction to be higher.

9) Professional certainty: value associated to "professions in which the individual has the certainty of keeping his job". This dimension in the present conditions from Romania, when the unemployment spectrum worrying, seems to be highly valued.

10) Physical ambiance: value associated to "professions characterized by satisfactory work conditions" (heat, silence, light, etc.)

11) Relationships with the superiors: value associated to "a job that is directed by a correct chief, with whom there can be established good relationships".

12) Relationships with colleagues: values associated to "a work activity that gives the possibility to some good social relationships with the colleagues". In the semi-classified activeties, this dimension is more important than the work nature in itself.

13) Lifestyle: value associated to "a work type that allows organizing your lifestyle the way you want".

14) Variety: value associated to "work activities that give the opportunity to exercising some varied operations".

15) Creativity: value associated to "a work that allows producing some new things, some new products. Creativity is related to the scientific interests from the Professional Interests Test by Martin Irle, adapted by S. Chelcea.

The score for each value direction is calculated as an arithmetic average of the appreciation of the three items composing that dimension. Thus the score can vary between 1 (lack of 
importance) and 5 (very high importance), reflecting the appreciation that the tested persons give to various aspects or work results.

The professional values inventory was applied on a sample of 120 students from "Gheorghe Asachi" Technical University of Iaşi (faculties of Electro-techniques and Electronics, $1^{\text {st }}$ year) with the purpose of identifying and setting a hierarchy of the new professional values that are shaped after 20 years from the revolution of December 1989 to the students of a technical university (Table 1). From the theoretical presentation of the values problematic, but also from the transformations that took place at the level of the Romanian society after December 1989 resulted the conclusion according to which values change according to the socio-economic context where they develop. This is the first hypothesis of the research made by us. In order to set the way the new professional values are organized, we have made the hierarchy of these values and their comparison to the hierarchy obtained by Septimiu Chelcea applying the same inventory on a sample of 600 de students, in 1996.

The second hypothesis refers to the specific of the hierarchy of professional values in the academic technical education. The profile of this hierarchy of professional values differs from one field to another, the academic education attracts some specific values on the first places.

After applying the professional values inventory and after centralizing the results, there was obtained their following general hierarchy.

Analyzing this professional values hierarchy, we can notice:

- The first three places belong to the: lifestyle, physical ambiance and the relationships with the superiors

- $\quad$ On the last 3 places there are work variety, leadership and prestige

- $\quad$ This hierarchy confirms the first hypothesis according to which values change according to the socio-economic context in which they develop. Because the socio-economic context characterizes itself by economic scanty growth, the employment difficulties in a convenient job, the managers' exaggerated importance, the most important values appreciated by students were: lifestyle, physical ambiance and relationships with the superiors.

Table 1.

Professional values general hierarchy.

\begin{tabular}{ccl}
\hline Rank & Professional Values & Average \\
\hline I. & Lifestyle & $\mathbf{1 3 . 1 5}$ \\
II. & Physical ambiance & $\mathbf{1 3 . 1 1}$ \\
III. & Relationships with the superiors & $\mathbf{1 2 . 7 6}$ \\
IV. & Economic advantages & 12.68 \\
V. & Creativity & 12.60 \\
VI. & Professional success & 12.54 \\
VII. & Professional certainty & 12.40 \\
VIII. & Independence & 12.14 \\
IX. & Intellectual stimulation & 11.92 \\
X. & Altruism & 11.81 \\
XI. & Relationships with the colleagues & 11.04 \\
XII. & Aesthetic values & 10.77 \\
XIII. & Variety & 10.75 \\
XIV. & Leadership & 10.52 \\
XV. & Prestige & 10.31 \\
\hline
\end{tabular}

- The second hypothesis underlines the specific of the chosen sample: students from a technical faculty that value the economic advantages, creativity and professional success.

- Because economic and social values are determinant, intellectual, prestige and leadership values are on the last places.

After applying the Professional values Inventory and centralizing the results, there was obtained the following differenttiated hierarchy on the two genders male (Table 2) and female (Table 3).

From the comparative analysis of the obtained results by boys and girls in our own research, we can identify the following differences:

- The first values are identical but the boys appreciate more physical ambiance and the girls' lifestyle.

- Economic advantages are better placed at girls than at boys, on the 3 rd place compared to the 4 th place.

- Creativity is placed on the 5 th place at girls and at boys on the 7 th place.

Table 2.

Professional values hierarchy for male gender (70 boys).

\begin{tabular}{ccl}
\hline Rank & Professional values & Average \\
\hline I. & Physical ambiance & $\mathbf{1 3 . 1 6}$ \\
II. & Lifestyle & $\mathbf{1 2 . 9 6}$ \\
III. & Relationships with the superiors & $\mathbf{1 2 . 7 6}$ \\
IV. & Economic advantages & 12.58 \\
V. & Relationships with the colleagues & 12.53 \\
VI. & Professional success & 12.48 \\
VII. & Creativity & 12.46 \\
VIII. & Professional certainty & 12.37 \\
IX. & Independence & 12.23 \\
X. & Intellectual stimulation & 12.05 \\
XI. & Altruism & 11.85 \\
XII. & Prestige & 11.12 \\
XIII. & Variety & 10.75 \\
XIV. & Aesthetic values & 10.67 \\
XV. & Leadership & 10.60 \\
\hline
\end{tabular}

Table 3.

Professional values hierarchy for female gender (50 girls).

\begin{tabular}{ccc}
\hline Rank & Professional values & Average \\
\hline I. & Lifestyle & $\mathbf{1 3 . 3 4}$ \\
II. & Physical ambiance & $\mathbf{1 3 . 0 6}$ \\
III. & Economic advantages & $\mathbf{1 2 . 7 9}$ \\
IV. & Relationships with the superiors & 12.77 \\
V. & Creativity & 12.75 \\
VI. & Professional success & 12.61 \\
VII. & Professional certainty & 12.43 \\
VIII. & Independence & 12.06 \\
IX. & Intellectual stimulation & 11.79 \\
X. & Altruism & 11.77 \\
XI. & Variety & 11.34 \\
XII. & Aesthetic values & 10.88 \\
XIII. & Leadership & 10.45 \\
XIV. & Relationships with the colleagues & 9.56 \\
XV. & Prestige & 9.50 \\
\hline
\end{tabular}


- Professional success is at the same 6th place for girls and boys, the girls having higher values.

- Prestige, leadership, work variety is at the last places for girls and boys.

Septimiu Chelcea obtained on the whole of the investigated group, the following hierarchy:

I. LIFESTYLE average 14.04

II. WORK AMBIANCE average 13.36

III. ECONOMIC ADVANTAGES average 12.90

At the opposed pole, there are the professional values related to leadership average 10.3 , to aesthetic values with an average of 10.49 and the work variety with an average of 10.86 .

From the comparative analysis of the results obtained by the students from the Technical University and the students from the group investigated by Septimiu Chelcea we can draw the following conclusions:

1) The general hierarchy is similar, more than that it confirms the first hypothesis of our research according to which the socio-economic context is determinant in setting a value hierarchy at a given moment.

2) At the opposed pole, there stand the same values: leadership, prestige, work variety, aesthetic values.

Both the results obtained by us as well as the ones obtained by $\mathrm{S}$. Chelcea can be explained by taking into account the radical socio-economic changes that took place in Romania after December 1989. In the present socio-economic context from Romania, as well as the one from the countries from Central and Eastern Europe - as Serge Moscovici remarks, in 1990there manifests a tension "communism and individualism". The freed society from despotic collectivism specific to the totalitarian regime orients towards an individualism as despotic and devastating. This is how it is explained the students' orientation towards values as lifestyle the way they want, work optimal physical conditions, economic advantages.

If we relate to the fact that $\mathrm{S}$. Chelcea realized his investigation in 1994, and we did it in 2009, there results the fact that during 15 years, the students' professional values hierarchy remained identical. This conclusion indicates the installation of certain stability of the value hierarchy, but unfortunately of a negative hierarchy, based on an extrinsic work motivation.

In the present social-economic situation, the students lose sight in a certain extent the intrinsic work motivating factors: work structure, creativity, professional fulfillment, factors that ensure personality self-fulfillment.
Relating ourselves to the re-structuring scheme of the value-attitudinal components from the Romanian society, we emphasize the fact that change has started with the behavioral level and we reached to stage of interests, attitudes, opinions, needs that will be reflected at the superior levels: beliefs, norms, mentalities and values. Action behaviors, immediate needs, individual beliefs are the ones that express the best the society development moment. The character of immediate, material profit, of individual welfare, at any costs even against the group interests, justice and fairness is predominant in defining value behaviors and attitudes.

\section{References}

Bushman, B., \& Baumeister, R. (1998). Threatened egotism, narcisism, self-estem, and direct and desplaced aggresson. Journal of Personality and Social Personality, 24, 75-87.

Crealia, R. (1996). Attitude heritability and attitude reinforcement: A replication. Personality and Individual Differences, 21, 803-808 doi:10.1016/0191-8869(96)00141-9

Chelcea S. (1994). Personalitatea şi societatea în tranziţie. Editura Ştiinţă şi Tehnică, Bucureşti.

Davis, M. H., \& Luce, C. (1994). The heritability of characteristics associated with dispositional empathy. Journal of Personality, 62, 369-391. doi:10.1111/j.1467-6494.1994.tb00302.x

Debono, K. G., \& Snyder, M. (1995). Actings on ones' attitude: The role of a history of choosing situations. Personality and Social Psychology Bulletin, 21, 629-636. doi:10.1177/0146167295216009

Eagly, A., \& Chaiken, S. (1998). Attitude structure and function. Handbook of social psychology. Boston: McGrow Company.

Ilut, P. (1995). Structurile axiologice din perspectivă psihosocială. Editura Didactică şi pedagogică, Bucureşti.

Radu, I., \& Ilut, P.(1994). Atitudini, valori, comportament,în I. Radu (coord.),Psihologie socială. Cluj-Napoca: Editura Exe,.

Rotariu, T., \& Ilut, P. (1997). Ancheta sociologică şi sondajul de opinie. Teorie şi practică. Iaşi: Editura Polirom.

Smith, P. B., \& Schwartz, S. (1997). Vallues. Handbook of cross-cultural psychology, 3. Boston: Allin and Bacon.

Super, D. E. (1953). A theory of vocational development. American Psychologist, 8, 185-190.doi:10.1037/h0056046

Super, D. E. (1990). A life span, life-space approach to career development. In D. Brown and L. Brooks (Eds.), Career choice and development (2nd ed.). San Francisco: Jossey-Bass.

Super, D. E. (1957). The psychology of careers. New York: Harper.

Tirhas, C. (2003). Personalitate multimodală în S.Chelcea şi P. Ilut (coord.). Enciclopedie de psihosociologie. Bucureşti: Editura Economică. 